\title{
Accountability in Hostile Times: the Case of the Peruvian Human Rights Ombudsman 1996-2001*
}

\author{
THOMAS PEGRAM
}

Abstract. This article examines the record of the Peruvian human rights ombudsman between 1996 and $200 \mathrm{I}$, seeking to explain its relative effectiveness under conditions of semi-authoritarian government. It suggests that this can be attributed to three factors: (I) the robustness of the institution's foundations; (2) the capacity of the first appointee and personnel, and; (3) the ability of the institution to build alliances which were able to enhance accountability. Drawing on O'Donnell's theory of a new generation of horizontal accountability mechanisms - that is, appointed, as opposed to elected, institutions - it argues that the human rights ombudsman occupied a distinct position in the Peruvian political system during this period that allowed it to interconnect different actors and arenas of accountability.

Keywords: ombudsman, accountability, Peru, democratisation, human rights, institutions

\section{Introduction}

The persistence of human rights violations and unstable citizenship rights in many ostensibly democratic states in Latin America has raised the spectre of democratic erosion or even breakdown. Yet one striking feature of the past 30 years has been the spread of the human rights ombudsman institution throughout Latin America. ${ }^{1}$ Mandated to protect citizens' fundamental rights, this new generation of horizontal accountability institutions is intended to strengthen democratic systems by protecting citizens' rights and upholding the constitutional order. However, the ability of the ombudsman to fulfil its mandate is often undermined by adverse political contexts.

Thomas Pegram is a DPhil candidate in Politics at Nuffield College, University of Oxford. Email: thomas.pegram@nuffield.ox.ac.uk

* I am grateful for the assistance of the University of Oxford's Latin American Centre, the Peruvian Defensoría del Pueblo and the Instituto de Estudios Peruanos in Lima. I particularly wish to thank Laurence Whitehead, Alan Angell, John Crabtree, Fredrik Uggla and several anonymous JLAS reviewers for their helpful comments on previous drafts of this paper.

1 Ombudsmen offices can be found in all Latin American democracies apart from Chile and Uruguay. 
Studies of the performance of these institutions may remain scarce, ${ }^{2}$ but a growing body of work points to the importance of political processes in explaining their variable records. ${ }^{3}$

The Peruvian model offers a particularly compelling case study for analysis. Paradoxically, although it was created by the semi-authoritarian regime of Alberto Fujimori, ${ }^{4}$ under the tutelage of its first appointee, Jorge Santistevan de Noriega (1996-2000), the Defensoría del Pueblo emerged from a process of institutional deconstruction and the aftermath of widespread human rights violations throughout the ig8os to perform a valuable democratic role. ${ }^{\mathbf{5}}$ From its creation in 1996 to the fall of the Fujimori Government in November 2000, the Defensoría operated, practically, as the sole democratic agent of accountability within the state and was recognised as such by civil society and international observers. ${ }^{6}$

Accountability theory is one of the most promising theoretical avenues for assessing the political agency of the ombudsman. Andreas Schedler argues that state institutions such as the ombudsman may still offer a degree of accountability even if they only exercise an answerability function - what might be termed 'soft' types of sanction including publicity and political measures. ${ }^{7}$ More demanding critics insist that enforcement powers are key and that in order for horizontal accountability mechanisms to be effective they must include the possibility of legal sanctions. ${ }^{8}$ The primary criticism often levelled at ombudsmen is that all too often they serve as democratic cover for less-than-democratic regimes. It is this theoretical debate which will broadly frame the article, complemented by an awareness of historical factors and broader institutional frameworks.

The ombudsman has proved to be a remarkably flexible and adaptive innovation. Yet the lack of a uniform conceptual model poses problems in terms of constructing a satisfactory criterion for assessing its effectiveness. ${ }^{\mathbf{9}}$ This study emphasizes three principal factors in order to explain the

2 See Linda Reif, The Ombudsman, Good Governance and the International Human Rights System (Boston, 2004).

3 Fredrik Uggla, 'The Ombudsman in Latin America,' Journal of Latin American Studies, vol. 36, no. 3 (2004), p. 448.

4 See David Collier and Steven Levitsky, 'Democracy with Adjectives: Conceptual Innovation in Comparative Research', World Politics, vol. 49, no. 3 (1997), pp. 430-5 I.

5 The Peruvian ombudsman translates into Spanish as the Defensoría del Pueblo.

${ }^{6}$ Coletta Youngers, 'Promoting Human Rights: NGOs and the State in Peru', in John Crabtree (ed.), Making Institutions Work in Peru (London 2006), p. I 70.

7 Andreas Schedler et al. (eds.), The Self-Restraining State: Power and Accountability in New Democracies (Boulder i 999), p. I4.

${ }^{8}$ Richard Mulgan, Holding Power to Account (Basingstoke 2003), p. Io.

9 International Council on Human Rights, Assessing the Effectiveness of National Human Rights Institutions, UNHCR (Geneva 2005). 
Defensoria's relative effectiveness in a far from ideal context: (I) the robustness of the institution's foundations; (2) the capacity of the first appointee and personnel, and; (3) successful alliance-building in order to enhance accountability. The selection of these three factors is supported by empirical analysis as well as by the inter-related but distinct questions regarding both the Defensoria's independent status and its ability to strengthen the democratic system overall.

Although this analysis focuses primarily on political processes of accountability, robust institutional design is also clearly vital. A broad and nonrestrictive mandate, combined with an all-encompassing jurisdiction, offers important counterweights to the ombudsman's lack of sanctioning power. The ombudsman's constitutional status, autonomy over appointment and recruitment procedures and, crucially, budgetary resources are all central concerns. Similarly, it may be useful to disaggregate the classical dual mandate of the ombudsman: to enhance parliamentary scrutiny over the executive, and to exercise judicial control over the public bureaucracy. The findings presented here suggest that both mandates may play an important role in defining the agency of the ombudsman in a context characterised by weak rule of law.

Beyond formal institutional indicators, this study draws on O'Donnell's notion of vertical and horizontal accountability and on Peruzzotti and Smulovitz's conceptualisation of social accountability, ${ }^{\mathbf{1 0}}$ arguing that the ability of the ombudsman to enter into alliances with actors in a range of dimensions, or arenas, of accountability is instrumental in explaining the relative effectiveness of the institution above and beyond its formal autonomy. As Ungar suggests, ombudsmen may become more powerful than initially expected, as their ability to secure allies and define and activate an effective oversight agenda increases. ${ }^{11}$

The political processes underlying these interactions also place the spotlight on the organisational capacity and leadership of the incumbent and personnel within the institution. O'Donnell's concept of 'appointed institutions' - a new generation of horizontal agencies intended to complement the work of existing 'balancing institutions' (the executive, legislative and judiciary), provides a useful point of departure. The functions of the Peruvian ombudsman can be analysed by disaggregating different actors and

${ }^{10}$ Guillermo O'Donnell, 'Horizontal Accountability in New Democracies', in Schedler et al., The Self-Restraining State, pp. 29-52. Enrique Peruzzotti and Catalina Smulovitz (eds.), Enforcing the Rule of Law: Social Accountability in the New Latin American Democracies (Pittsburgh 2006).

11 Mark Ungar, Elusive Reform: Democracy and the Rule of Law in Latin America (Boulder 2002), p. 37 . 
modes of action within the arena of horizontal accountability. ${ }^{12}$ Such agencies include electoral commissions, state auditors, anti-corruption agencies and ombudsmen. This article aims to contribute to theoretical debate by empirically assessing the ability of an appointed institution to enhance accountability in the face of considerable adversity. Furthermore, in considering the extent to which the Defensoría constituted a special case amongst horizontal accountability institutions in Peru, it contributes to further conceptual refinement of an important sub-type of horizontal accountability.

Peruzzotti and Smulovitz assert that social accountability mechanisms - involving organised sectors of civil society and the media - may initially constitute a response to certain institutional deficits, but that they can subsequently focus their attentions on institutional capacities in other arenas or agencies. ${ }^{13}$ The experience of the Peruvian Defensoria reaffirms that such a positive synergy can be achieved between horizontal and social accountability. ${ }^{14}$ This relates particularly to the cultivation by the Defensoría of a range of alliances with accountability actors outside the state able to exert influence on the political system and public bureaucracies. Described by Pastor as the 'third dimension', alliances cemented with external actors of accountability are also a significant resource. ${ }^{15}$

Finally, by indicating both the direction of exchange and the arenas in which it takes place, O'Donnell's theory of accountability provides a useful platform from which to explore the interactions within and between different arenas of accountability. Although this theory was originally designed to deal with cases of weak or low quality democracies, it is increasingly clear that there is a wide range of hybrid regimes where the question of horizontal accountability as theorised by O'Donnell and others can provide important insights. In this particular case, the hybrid regime in Peru under Fujimori, despite its authoritarian bent, still allowed for the existence of the ombudsman. Whereas O'Donnell has argued that democracies can endure in the absence of horizontal accountability, it is demonstrated here that under

12 O'Donnell defines appointed institutions as: (I) proactive and continuous in their respective tasks; (2) able to invoke professional or 'apolitical' criteria and thus diminish conflict; and (3) specialised where necessary to investigate the political bureaucracy. Guillermo O'Donnell, 'Notes on Various Accountabilities and Their Interrelations', in Enrique Peruzzotti and Catalina Smulovitz (eds.), Enforcing the Rule of Law: Social Accountability in the New Latin American Democracies (Pittsburgh 2006), p. 338.

13 Peruzzotti and Smulovitz, Enforcing the Rule of Law, p. 35 I.

${ }^{14}$ Catalina Smulovitz and Enrique Peruzzotti, 'Societal and horizontal controls: two cases of a fruitful relationship', in Scott Mainwaring and Christopher Welna (eds.), Democratic Accountability in Latin America, (Oxford, 2003), pp. 309-32.

15 See Robert Pastor, 'The Third Dimension of Accountability: The International Community in National Elections', in Schedler et al. The Self-Restraining State, pp. I 23-44. International agencies refer to a variety of different actors, including national governments, IGOs, international judicial bodies and international NGOs. 
certain conditions, mechanisms of horizontal accountability can persist and have an impact, even as a democratic system degenerates into a hybrid of democracy and authoritarianism.

\section{Semi-authoritarianism in Peru}

During the I980s and I990s, the relationship between state and society in Peru was shaped by the implosion of the economy and state, and the emergence of the violent, subversive group Sendero Luminoso (Shining Path). Large swathes of the country were effectively what O'Donnell has termed 'brown areas'; spaces where liberal guarantees and the rule of law were absent and subject to violation by state agents. ${ }^{\mathbf{1 6}}$

In response to this vacuum of political accountability, Peru witnessed the rapid growth of social actors intent on restricting the arbitrary power of the state. However, these met with only limited success. ${ }^{17}$ Growing domestic and international pressure during the late ig8os helped to create the Fiscalia Especial de Defensoría del Pueblo y Derechos Humanos (Special Prosecutors of the People's Ombudsman for Human Rights) in April i 989. However, the office remained a department of the Ministerio Público (Public Prosecution Service) and was answerable to the assistant Attorney General, raising serious questions about its operational autonomy and organisational integrity. ${ }^{\mathbf{1 8}}$

In the midst of economic collapse under the Garcia administration (1985-1990) and the popular rejection of Mario Vargas Llosa as the traditional political elite candidate, Alberto Fujimori, a political outsider, won the Presidential election of I990. The new political system constructed following the 1992 autogolpe or 'self-coup' and subsequent approval of a new constitution in 1993, was marked by extensive clientelist practices, with Fujimori largely beholden to military patronage. This was combined with the far-reaching and corrupt influence of Fujimori's 'personal advisor', Vladimiro Montesinos, and his control over the National Intelligence Service (SIN). In institutional terms, as Ellner has noted, Fujimori's political project was striking in its 'institutional barrenness' 19 - the new president overseeing the deconstruction of those democratic institutions, however flawed, that had previously existed.

16 Guillermo O’Donnell, 'On the State, Democratization and some Conceptual Problems', The Helen Kellogg Institute, Working Paper 192, April 1993.

17 The most prominent actor to emerge was the Coordinadora Nacional de Derechos Humanos (National Human Rights Coordinating Committee) established in 1985.

18 See Mauricio Novoa, Defensoría del Pueblo: Aproximaciones a una Institución Constitucional (Lima 2003).

19 Steve Ellner, 'The Contrasting Variants of the Populism of Hugo Chavez and Alberto Fujimori', Journal of Latin American Studies, vol. 35 (2003), pp. I39-62. 
Within this unpropitious context, the 1993 Constitution approved a variety of democratic innovations as a political act of good faith to the international community; these were not seen as contradictory to the central thrust of the Fujimori project. Neither the important modifications approved to the remit of the Constitutional Tribunal, ${ }^{20}$ nor the new Defensoria del Pueblo, provoked much debate. The latter particularly enjoyed antecedents within the Ministerio Público and strong international support. ${ }^{21}$ The World Bank Lima office was particularly engaged in lobbying for the Defensoría. ${ }^{22}$ As Jorge Santistevan, the first ombudsman appointed to the post, stated:

You have to understand, in 1993 nobody really understood what the Defensoría was and even less, gave it any importance. I had lived in Mexico and Central America, where the institution first began - in Guatemala. From this experience, I had a good idea of the potential of an institution such as the Defensoría. ${ }^{23}$

It appears that Fujimori and his inner circle had little notion of the oversight role the Defensoría would eventually play in upholding the constitutional order and human rights. ${ }^{24}$ However, it is also true that the Constitution of I 993 succeeded in decisively shifting the balance of power in favour of Fujimori, despite its dubious legality. ${ }^{25}$

\section{Institutional Foundations}

In order for the ombudsman to act as an accountability agent, a strong legal underpinning is an important prerequisite. The Defensoría's constitutional safeguards of independence, jurisdiction and powers are, on paper, robust. Table I details the principal attributes of the institution, with particular reference to its functional, administrative and budgetary independence.

The distinctive design of the ombudsman, particularly its lack of coercive authority, underlines the complementary role it is conceived to perform within a network of horizontal accountability institutions. The institution enjoys certain legal prerogatives with comprehensive and far-reaching powers of investigation. The Peruvian ombudsman has unrestricted authority to initiate investigations proactively, or respond to complaints, petitions or

20 The Constitutional Tribunal is the highest legal authority in matters of constitutionality of Peruvian laws and decrees. Included in the 1993 Constitution and re-established in June 1996 it was effectively shut down by a Fujimori controlled congress in May 1997.

21 Author's interview with Deputy Defensor for Constitutional Affairs Samuel Abad, I 4 July 2005.

22 Author's communication with World Bank Group, 2i February 2006.

23 Author's communication with Defensor del Pueblo Jorge Santistevan, 22 February 2006.

24 Author's interview with Magistrate of the Constitutional Tribunal César Landa, 22 July 2005.

25 The Constitution was approved by the narrowest of margins by popular referendum in I 993 - a process criticised for irregularities. 
Table i. Attributes of the Defensoria

Function

Independence

Immunity

from

Prosecution

Incompatibility

Election

Term of office

Grounds for

Dismissal

Budget and

Resources
Attributes

The Defensoría is independent. Public bodies are obliged to cooperate with the Office of the ombudsman when it so requires. The Defensoría enjoys total independence in the exercising of its functions. It is subject to no imperative mandate, nor receives instruction from any authority. It is subjugated only to the Constitution and its own Organic Law.

The Defensor enjoys the same immunity and prerogative as afforded to members of Congress.

The position of Defensor is incompatible with the exercising of any other position of public office or private profession.

The Defensor is elected by a majority vote of two thirds of Congress. ${ }^{1}$

The Defensor is elected for a term of five years and may be re-elected once only.

The Defensor may be dismissed for negligence in the carrying out of his or her duties and obligations, among others. ${ }^{2}$

The annual budget project is presented for approval by the titular before both the executive and Congress.
Legal basis

1993 Constitution, Art. I6I

1993 Constitution, Art. I6I

1993 Constitution, Art. I46, I6I

1993 Constitution, Art. I6I

1993 Constitution, Art. I6I

Organic Law, Art. 4

Organic Law, Art. 34

Source: Defensoría del Pueblo, Primer Informe del Defensor del Pueblo al Congreso de la República 1996-1998 (Lima 1998).

1 The high majority required implies a certain degree of coordination and dialogue within Congress in order for the candidate to be elected.

2 Other more common grounds for dismissal include: renouncement of office, expiry of term, death, physical or mental incapacity, and incompatibility of office.

consultations presented to it. Furthermore, public entities, with few exceptions, ${ }^{26}$ are legally obliged to co-operate with the ombudsman's investigations.

In terms of the institution's jurisdiction, the legal mandate to protect 'constitutional and fundamental rights' contained in Article 162 of the constitution is sufficiently ambiguous to facilitate creative interpretation, extending even to oversight of the electoral process (as discussed below). In effect, the Defensoría's jurisdiction extends beyond human rights violations and abuses of public office to encompass supervision of the state administration and public services. Although not explicitly addressed in the legal foundations of the institution, the role of mediator is a natural extension of

26 This legal obligation of cooperation is limited in relation to: (a) judicial secrecy (including military courts), and; (b) national security, defence and international relations. 


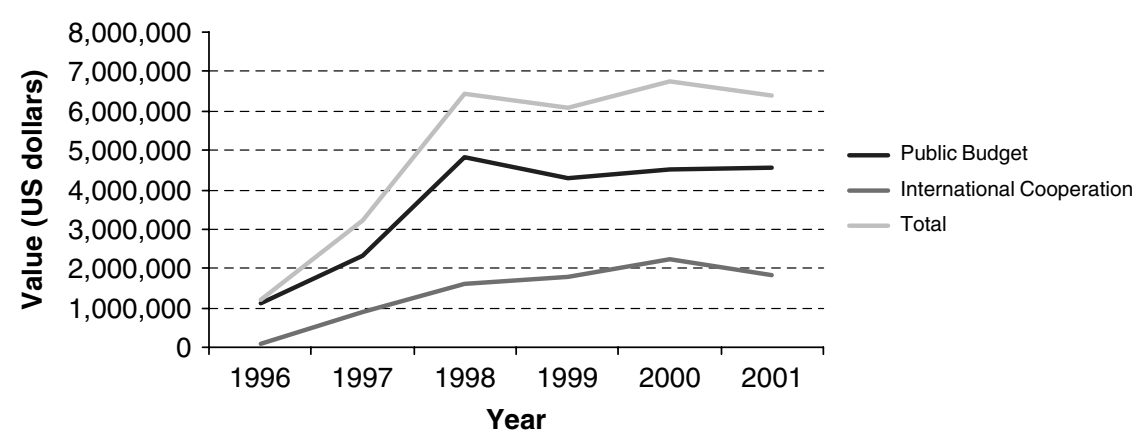

Graph I. Budget 1996-200I (in US dollars). Source: Annual Reports accessed at: wnw.ombudsman.gob.pe.

the Defensoría's mandate, in particular regarding the issuing of non-binding recommendations, resolutions and reports.

Finally, although the Defensoría may lack legally binding powers, the ability of the Defensor to present actions of unconstitutionality to the Constitutional Tribunal and to petition the Inter-American Court of Human Rights reflects the institution's intrinsic relationship with the democratic rule of law and human rights. Furthermore, inspired by the Spanish ombudsman model, the Defensoría is empowered to initiate judicial processes in defence of human rights. ${ }^{27}$

\section{Budgetary Independence}

Reflecting the regional norm, the Defensoria's budget is allocated by the legislature. As is the case with other ombudsmen in the region, public expenditure is inadequate given the breadth of the institution's mandate. In I 998 , central funding for the Defensoría totalled US $\$ 4.8$ million, compared to a judicial budget of US $\$ 90$ million. ${ }^{28}$ Despite insufficient funding and a budget freeze in 1999, it appears that the institution was not subjected to overtly politically motivated reductions. Certainly, this did not occur on a scale witnessed elsewhere in the region, such as in Ecuador where the Defensoría's budget was slashed by 40 per cent in $1999 .{ }^{29}$

As can be seen in Graph I, from an early stage, the Defensoría drew upon the public purse and from a range of international donors such as the World Bank and some bilateral agencies. Between 1996 and 2002, the Defensoría received a total of US\$I million from international sources, approximately a third of its total income. As with many regional ombudsmen, the Peruvian

${ }^{27}$ Most hybrid ombudsmen have additional powers to initiate court actions in order to protect human rights.

28 Source: www.mef.gob.pe. Accessed i 2 April 2006.

${ }^{29}$ Ungar, Elusive Reform, p. 4I. 


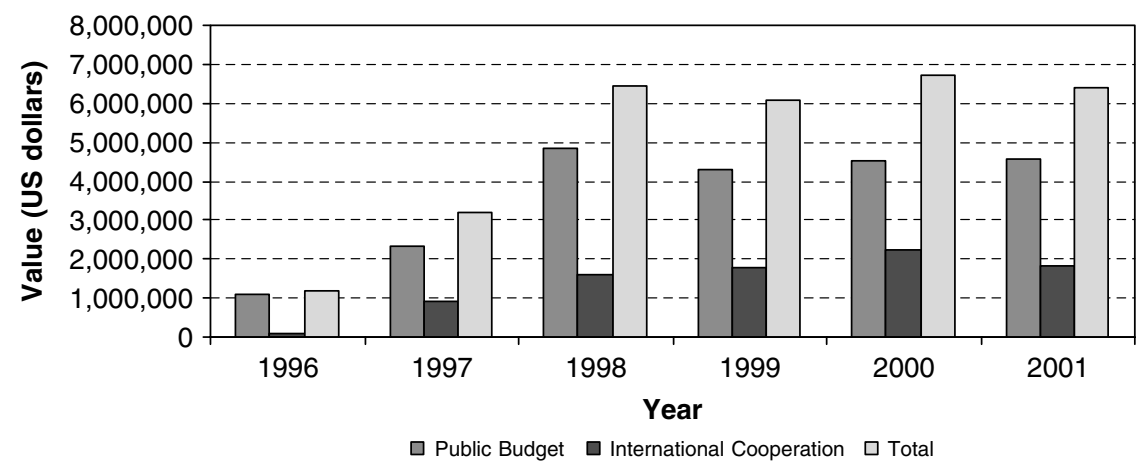

Graph 2. Budget by source of finance (in US dollars). Source: Annual Reports accessed at: www.ombudsman.gob.pe.

Defensoría utilised this relationship with international agencies in order to bolster its independence from the state. ${ }^{30}$ Although all international funding had to be coordinated with the Technical Secretary of International Cooperation (SECTI) of the Ministry of the Presidency, and, in the case of international bank loans, the Ministry of Economy and Finance (MEF), it appears that the Defensoría did not suffer interference in these transactions.

Such dependence on foreign aid was a cause of financial instability. As Graph 2 illustrates, at its height, during the election year of 2000, international funding accounted for 33 per cent of the Defensoría's total budget. In order to counter this dependence the Defensoría successfully negotiated funding from the MEF, particularly during 1998, partly through an effective media strategy.

\section{Appointment and Recruitment Procedures}

It is important to recognise that, as with other ombudsmen in the region (notably in Ecuador), political reliance upon Congress in terms of appointment procedures and, to some extent, the budget, undermines the independence of the institution and may have serious consequences for institution-building. The ombudsman is something of an incongruity in a presidential system, mandated to monitor the actions of two ostensibly independent powers (the executive and the judiciary), and appointed by and accountable to the third (the legislature) ${ }^{31}$

${ }^{30}$ Foreign funding of ombudsmen varies throughout the region. Available figures for $200 \mathrm{I}$ suggest that foreign funding as a percentage of total budget was $50 \%$ in Bolivia, $39 \%$ in Colombia, $40 \%$ in Honduras, $15 \%$ in Guatemala and $10 \%$ in El Salvador: Uggla, 'The Ombudsman', p. 436.

${ }^{31}$ See Uggla, 'The Ombudsman', p. 426. 
The precariousness of this arrangement is demonstrated by the sharply contrasting experiences of Peruvian ombudsman Jorge Santistevan (1996-2000) and his acting successor, Walter Albán (200I-2005). Albán was repeatedly thwarted in his attempts to receive official endorsement as Defensor del Pueblo, while in 1996 the Defensoría was an unknown political quantity and Santistevan's candidature was quickly accepted by a Fujimoricontrolled congress with a comfortable majority of 95 to $15 .{ }^{32}$ The highprofile role of the Defensoría during the 2000 elections, combined with Santistevan's ill-advised decision to resign as Defensor in order to enter the presidential race in late 2000 , transformed perceptions of the institution's political capital.

The Peruvian experience points to the potential for this hierarchical relationship to conflict with the integrity of the institution. As Lerner notes, 'sadly, it is inevitable that an institution such as the Defensoría in the Peruvian context would be subject to political calculation and congressional negotiation. ${ }^{33}$ This dynamic has not abated in recent years, with relations between congress and the Defensoría often becoming highly conflictive. ${ }^{34}$ The current Ombudswoman, Beatriz Merino, a former President of the Council of Ministers, was elected in November 2005, having secured the necessary consensus in congress prior to presenting her candidature. ${ }^{35}$

Regardless of how the Defensor is appointed, a crucial element in the ability of the institution to fulfil its mandate is the calibre of its personnel. In the case of the Peruvian Defensoría, the quality and continuity of its staff has been identified as a key factor behind the high degree of institutional success enjoyed by the institution. ${ }^{36}$ Granted full autonomy in recruitment by the Organic Law, Santistevan sought candidates with credibility, quality and commitment. Beginning with the appointment of Albán, a well-respected human rights lawyer and active member of civil society, as Deputy Defensor on 20 July 1996, Santistevan went on to recruit other prominent members of civil society including Rocio Villanueva (Defensora in Women's Rights) and Samuel Abad (Defensor in Constitutional Affairs) in November of the same year. The core leadership of Santistevan, Abad and Villanueva was augmented in early 1998 when Gino Costa was named as Deputy Defensor for Human Rights and José Távara appointed to monitor Public Services.

32 Santistevan was also assisted by his international credentials as a former UN official, his apparent political neutrality, and a domestic network of support which spanned government and civil society.

33 Salomón Lerner, interview by author, io August 2005, Lima, Peru. Salomón Lerner is the Ex-President of the Peruvian Truth and Reconciliation Commission.

34 See Édgar Núñez, 'Debilidad ante la violencia', in El Peruano, I 3 July 2007.

35 La Republica, 30 September 2005.

36 Marcial Rubio, interview by author, 7 September 2005, Lima, Peru. 
The result was a staff which had little or no previous experience of working within the state. The continuity of the Defensoria team is also significant. With very few changes or rotation of personnel at the highest echelons of the institution, a culture of 'gente de confianza' (trusted confidants) was formed within the institution. ${ }^{37}$

\section{Actors and Arenas of Accountability}

As O'Donnell states, 'achieving a significant degree of ... accountability requires the coordination of several agencies. ${ }^{, 38}$ The Defensoría's operational ability to fulfil its mandate, especially in terms of enforcing legal accountability, was in part dependent upon the existence of a network of horizontal accountability institutions with the requisite legal authority, willingness and information. Due to the institutional 'hollowing out' of the state engineered by Fujimori, the Peruvian Defensoría turned its attention to cultivating relationships with actors in arenas of accountability outside the state - both social accountability mechanisms and international agencies, in order to activate its mandate.

\section{Horizontal accountability: a loss of balance}

In a scenario where all power flowed from the executive, the nature of the Defensoria's interaction with other state institutions became largely conditional upon the client status of that respective institution with the executive. Although the Defensoría was no client of Fujimori, a working relationship existed until the Defensoría's decision in I 999 to weigh in on the electoral issue. As Santistevan recalled, 'at the outset, the relationship with Fujimori was one of respect and even collaboration; it was only later that things turned sour' ${ }^{39}$ Indeed the ability and willingness of the Defensoria to intervene in cases of administrative inefficiency or malpractice, such as expediting child support claims, was a new resource, and one which was actively promoted by Fujimori. ${ }^{40}$

The Defensoría also benefited from its lack of political affiliation, as Santistevan emphasised in an interview in April 1997: 'I am convinced that the task of representing the citizen before the state has to be, by definition, apolitical, completely apolitical'.$^{41}$ Despite such assurances, the relationship between the executive and the Defensoría can be described as fragile, characterised as it was by a lack of communication, ${ }^{42}$ and as

\footnotetext{
37 Rubio, 7 September 2005.

39 Santistevan, 22 February 2006.

38 O'Donnell, 'Horizontal Accountability', p. 45.

40 Expreso, i 8 November 1999.

41 Cuestion de Estado, Instituto de Dialogo y Propuestas, no. 27 (Abril i997) pp. I 8-9.

${ }^{42}$ Abad, I4 July 2005.
} 
early as December 1996 Santistevan pointed to signs of friction. ${ }^{43}$ The relationship would become increasingly strained in the run-up to the 2000 elections.

With the oficialista party Cambio 9o-Nueva Mayoría enjoying a majority in the single-chamber congress introduced in 1993, and opposition political parties discredited, Fujimori could rely on congressional endorsement. This client status meant the Defensoría had few allies in the legislature. This was also the case for the judiciary and Ministerio Público. The creation of executive commissions of the judiciary on 2 I November 1995 and a similar body for the Ministerio Público on 3 November 1996, ostensibly to monitor an institutional reform programme, served to politicise both institutions until their deactivation in $2000 .{ }^{44}$

The legal arena presented the Defensoría with its most severe challenges. For its part, the judiciary became a partisan political tool of Fujimori, with the Supreme Court packed with supporters of the president. Acts of judicial connivance quashed societal opposition to the regime and prominence was given to the military judicial system within areas commonly beyond its jurisdiction. The controversial dismissal by Congress of three magistrates of the Constitutional Tribunal in May 1997 removed one of the Defensoría's fundamental channels of judicial recourse. During the short time in which the Defensoría operated alongside the Constitutional Tribunal, it presented seven actions of unconstitutionality. Following the dismissal proceedings, although the Tribunal continued to function, relations with the Defensoría rapidly deteriorated, reflected by a breakdown in collaboration. $^{45}$

The Defensoria's ability to seek enforcement was therefore dependent to a large extent upon the discretion of a politically hostile horizontal accountability arena. In practice, congress usually ignored its oversight function. As Santistevan reflected:

The Defensor del Pueblo acts much like a doctor who diagnoses a condition. The surgery he must leave to another. If congress has not taken into account our position, nevertheless, our opinion remains very clear. ${ }^{46}$

Similarly, resistance was encountered from within the insular confines of the judiciary, which regarded the Defensoría with suspicion. The judiciary only

43 The day following the hostage taking of the Japanese Ambassador's Residence, the Defensoría called for dialogue, respect for human rights and a proportionate response on the part of the authorities.

44 See Javier De Belaunde, 'Justice, Legality and Judicial Reform', in John Crabtree and Jim Thomas (eds.), Fujimori's Peru: The Political Economy (London i 998), pp. 173-91.

45 Between 1998 and 1999 the Defensoría submitted only two amparo actions, one of which was a joint action. Defensoría del Pueblo, Segundo Informe del Defensor del Pueblo al Congreso de la Republica 1998-1999 (Lima 1999), pp. 339-4I.

${ }^{46}$ Expreso, I 2 June i999. 
cooperated with the Defensoría in 25 per cent of all cases presented between I 996 and $1998 .^{47}$

\section{Individual participation}

As a horizontal accountability mechanism, the Defensoría offers the citizen an institutional channel of appeal. Citizens can solicit the intervention of the Defensoría in writing, by telephone, via the internet, or in person. Given the high rate of illiteracy in Peru, especially amongst the most vulnerable sectors of society, the ability to lodge a verbal claim with the Defensoría has proved highly significant.

On a theoretical note, a restricted notion of accountability agency may require that individuals can only be considered 'social accountability actors' if their petitions to accountability mechanisms are framed in a language of rights and legality and do not appeal, at least directly, to material interests. ${ }^{48}$ In part, this proviso recognises that the success of such petitions and their ability to trigger the social-horizontal network will depend largely on the collective organisation of the claimants. Without elaborating on the wider implications of these observations, in analysing the Defensoría it is useful to make the distinction between individuals taking petitions to the institution and the Defensoría advancing 'class actions' on behalf of marginalised or excluded groups.

Although recognising the importance of the Defensoria's capacity to receive and respond to complaints from the citizen, the Defensor and his team noted early on a number of limitations in simply responding to individuals. The 1998 annual report shows 72 per cent of claimants to be men between 35 and 65, highlighting the lack of claims lodged by vulnerable groups such as the young, women and the elderly. This was compounded by the confusion often shown by citizens toward the institution and a profound lack of a rights culture in Peruvian society. As Abad observed:

Sometimes complaints would arrive that were completely inadmissible, or sometimes just patently absurd. We soon realised that if we just responded to the complaints we received we would lose sight of other relevant subjects. So we began to search for issues that had a more global sweep. ${ }^{49}$

The Defensoría applied itself to identifying those groups most excluded from the political system and finding ways in which the institution could

47 'Cooperation' is defined as 'the total disposition of the institution in question to the requirements and recommendations of the Defensoría'. This is not to be confused with cooperation vis-à-vis third parties. Defensoría del Pueblo, Primer Informe, p. 35 I.

48 O'Donnell, 'Notes on Various Accountabilities and Their Interrelations', in Peruzzotti and Smulovitz, Enforcing the Rule of Law, p. 342.

49 Abad, I4 July 2005. 
provide an arena for their inclusion. This was most clearly expressed in the decentralisation of its operations, not only with provincial offices, but also via mobile units equipped to travel to remote communities and disseminate rights information. Yet while the local offices and mobile units served an important purpose, the experience of the Defensoría outside Lima revealed the difficulties of connecting with those people most excluded. As advisor to the Defensor, Rolando Luque commented in 2005, 'I must confess that we are still a Defensoría of the middle class. We have not yet resolved the matter of how to be the Defensoría of the most vulnerable'.50

This points to a range of challenges for an institution which has attempted to bridge state and society in Peru, including a scarcity of institutional resources, negative perceptions of the state by the citizenry and, in the case of human rights, the pre-existence of a range of alternative, non-governmental agencies. Despite the institution's undoubted achievements, the challenge remains to meet the needs of the most excluded sectors whose rights are often poorly recognised. ${ }^{\mathbf{5 1}}$ This is an objective to which social and external actors can clearly contribute.

\section{The media}

The manipulation of the media was a defining characteristic of the Fujimori era. However, this did not preclude the Defensoría from enjoying a working relationship, particularly with the print media, which was actively encouraged at the outset by Fujimori. The Defensoría and Santistevan quickly developed a publicity strategy that relied on the media as an essential conduit to a wider constituency and exposure, reflecting Peruzzotti and Smulovitz's recognition of the media as an important source of social accountability giving visibility to accountability actions. ${ }^{\mathbf{5 2}}$

The working relationship between the Defensoría and important sections of the media leading up to 2000 can be largely explained by two key factors. Firstly, Fujimori's control of the media was never complete. The Defensoría made good use of the written press, confronting the regime indirectly, and distinguishing itself by adopting a less confrontational stance on classic issues of protest such as human rights and press freedom, while insisting that democratic solutions and respect for the rule of law must prevail. Secondly, the imagery of modernity and transformation used in Fujimori's political

Author's interview with Advisor to the Defensor del Pueblo Rolando Luque, i 5 July 2005.

${ }^{51}$ Between 1996 and 1998,38 percent of complaints originated from central Lima, followed by the city outskirts. Defensoría del Pueblo, Primer Informe, p. 87.

${ }^{52}$ Enrique Peruzzotti and Catalina Smulovitz, 'Civil society, the media, and internet as tools for creating accountability to poor and disadvantaged groups', UNDP, Occasional Paper (2002/I 3), p. Iо. 
rhetoric came to the forefront in the 1995-1997 period. The Defensoría epitomised this process of renewal and internationalism. ${ }^{\mathbf{5 3}}$

The capacity of the Defensoría to navigate the media came to the fore in the budgetary negotiations with the MEF in September I997, when Santistevan went on a media offensive. Banking on popular support and continuing positive media attention, he announced the decision to create three new specialized Defensores during the following months, tying this initiative explicitly to the polemical issues of public services and the budget negotiations. In an article published in El Peruano on 4 September 1997 he stated:

We hope that with the 1998 budget we will be able to put the plan into practice, but this will depend entirely on the size of the budget. ${ }^{\mathbf{5 4}}$

Behind closed doors, the Defensor was also in negotiations with the international donor community to enlist its support. The announcement on I9 September by USAID that it would be increasing its initial offer of aid for the period up to September I 999 from US\$250,000 to US\$750,000 was well timed to put maximum pressure on the financial authorities. ${ }^{\mathbf{5 5}}$ Emboldened by this massing of support, the Defensor rejected the MEF's initial offer of US\$3,686,000. ${ }^{\mathbf{5 6}}$ Eventually the institution secured US\$4,8 29,3 I 4, an increase of over roo per cent on the r997-1998 budget allocation. ${ }^{\mathbf{5 7}}$

\section{International cooperation}

The international presence in Peru and its influence over the Fujimori regime was significant, reflecting the international community's democratic and human rights agenda toward Peru. ${ }^{58}$ The creation of the Defensoría also coincided with a growing interest in ombudsmen and national human rights institutions within the Organisation of American States (OAS), signalled in I 997 with a declaration calling for their establishment in all member states. ${ }^{\mathbf{5 9}}$

Upon assuming office, Santistevan began to enlist a wide array of potential guardians. As he recalled, 'I knew that if the government decided to pressure the Defensor or the institution it would be essential that international cooperation and the embassies step up to defend the institution'. ${ }^{\mathbf{6 0}}$ As detailed below, this resource was evident in the strong defence of the Defensoría by the diplomatic community during the election process of

53 El Peruano, 29 April i 997.

55 Comercio, i9 September i 997.

57 Conversion to US\$ from Peruvian soles at XR: $\$ \mathrm{I}=\mathrm{S} / .3 \cdot 5$.

58 Fujimori felt impelled to brief the OAS Commission after the i 992 coup to reassure them that democracy would be quickly restored to Peru.

59 OAS General Assembly: Support for International Exchanges Among Ombudsmen, OAS AG/RES i 505, XXVII-o/97 (June 5, I997).
60 Santistevan, 22 February 2006. 
$2000 .{ }^{61}$ In turn, the Defensoría struck up profitable relationships with a range of aid bodies. Above all, in a scenario of institutional deconstruction, the ability of the Defensoría to produce results in difficult operational circumstances impressed the international donor community. ${ }^{62}$

\section{Organized sectors of civil society}

In contrast to the varying experiences of other regional ombudsmen, ${ }^{63}$ the Peruvian model cultivated a strong support base in society, in part thanks to a highly organised (though largely urban) human rights network and the direct transfer of personnel from respected organisations to the Defensoria. ${ }^{64}$ In order to withstand the most repressive years of the Fujimori regime, relationships with diverse actors were developed to create what Santistevan describes as the institution's 'four shields'. ${ }^{65}$ These principal allies were civil society (chiefly the human rights community and civic and consumer associations), the church, the media and international donors.

Santistevan frequently referred to the role of the Defensoría as a 'bridge between the state and civil society' ${ }^{66}$ It is interesting to note that this role was not foreseen in its constitutional design. Instead, through a conscious strategy originating as much from within the Defensoría as from influential actors within civil society (such as the Coordinadora and Transparencia ${ }^{67}$ ), alliances were forged on common ground. ${ }^{68}$

The relationship was not always harmonious. Initially, the Defensoría was criticised for siphoning off valuable personnel and some funding. Fears were also raised that it would become little more than a 'seat of honour'. ${ }^{69}$ Additionally, the operationalisation of the Defensoría was far from homogenous throughout the country. However, despite some criticism, the committed actions undertaken and results achieved by the

61 Interview with John Hamilton (US Ambassador), Ideele, no. I 27, April-May 2000, p. I 8.

${ }^{62}$ Alza, 6 July 2005.

63 See Michael Dodson, 'The Human Rights Ombudsman in Central America: Honduras and El Salvador Case Studies', Essex Human Rights Review, vol. 3, no. I (2006).

${ }^{64}$ Coletta Youngers, 'Promoting Human Rights', p. 172.

${ }^{65}$ Santistevan, 22 February 2006.

${ }^{66}$ Jorge Santistevan, 'Defensor que no critica, que renuncie'. Interview in Ideele, Revista del Instituto de Defensa Legal, no. I I9 (June 1999), p. 22.

67 Established in 1985 , the Coordinadora Nacional de Derechos Humanos (National Human Rights Coordinating Committee) acts as an umbrella organisation coordinating the activities of more than 60 human rights organisations across Peru. Transparencia is a domestic NGO created in 1994 with the goal of monitoring elections.

68 Author's interview with Director of the Defensoria's Office of International Cooperation Félix Grandez, i 8 July 2005.

69 Author's interview with advisor at the Instituto de Defensa Legal Gorge Farfan, 26 August 2005 . 
Defensoría on the national stage were widely recognised as outweighing the negatives. $^{\mathbf{7 0}}$

High profile national processes driven by the Defensoría in the political and civil sphere (such as the Ad Hoc Commission on prisoners indicted on terrorism charges), protection of reproductive rights, and the curtailment of military justice, stand out as important achievements during the I996-2000 period and were recognised as such by the human rights community. The following brief overview of three high-profile initiatives points to the interaction of the Defensoría with other actors in different arenas of accountability. In particular, the institution's ability to adopt a combination of accountability strategies in alliance with social and external actors and accurately assess available resources was apparent. 'Multiple activation' of strategies and interaction across arenas of accountability were critical for the achievement of accountability outcomes. ${ }^{\mathbf{7 1}}$

\section{The Ad Hoc Commission}

Established in August I996, the Ad Hoc Commission was the culmination of years of pressure from the human rights community and seven failed legislative initiatives aimed at addressing the issue of thousands of innocent Peruvians held in jail on dubious terrorism charges. The credit for overcoming resistance in congress, the executive and human rights organisations, in order to reach a consensual solution, is largely attributed to Santistevan. $^{\mathbf{7 2}}$

The Commission was far from ideal, empowered as it was to recommend presidential pardons to prisoners deemed innocent, rather than absolve them of their crimes. Nonetheless, by the time its mandate expired at the end of I 999 it had succeeded in securing the freedom of 5 I 3 individuals.

The human rights community initially had serious misgivings about the Ad Hoc Commission, reasoning that the rule of law was effectively subverted to the will of the president and fearing that the Commission would legitimise the highly controversial amnesty laws passed a year earlier. However, the community also accepted the view that an imperfect solution was better than none at all. ${ }^{73}$ For his part, Santistevan argued strongly in favour of seizing the

70 Author's interview with Executive Secretary of the Coordinadora Francisco Soberon, I6 August 2005 .

71 See Ana-Tereza Lemos-Nelson and Jorge Zaverucha, 'Multiple Activation as a Strategy of Citizen Accountability and the Role of Investigating Legislative Committees', in Peruzzotti and Smulovitz, Enforcing the Rule of Law, pp. 75-I I 4.

72 Gino Costa, 'Dos Anos de la Comision Ad-Hoc: Resultados y Perspectives', Debate Defensorial: Revista de la Defensoría del Pueblo, no. I (September i 998), pp. i 27-42.

73 Youngers, 'Promoting Human Rights', p. 74 
initiative. With the issue in the media spotlight, he believed concrete results could be achieved quickly:

The subject had been promoted by NGOs, and later taken up by the media. The exposure became so great that Fujimori himself became personally interested in the subject. It seemed to me that it was best to act and secure results quickly. It was a purely political calculation; from a legal point of view it left much to be desired. ${ }^{74}$

Working together with social actors to denounce violations, the Defensoría undoubtedly made an impact. For instance, it is widely believed that the creation and activity of the Ad Hoc Commission created a more propitious environment for the gradual, but progressive, dismantling of the security state inherited from the early I 990 os onwards. ${ }^{75}$

\section{'Voluntary Anti-contraceptive Surgery'}

Non-confrontation was not always the rule of the game, even before 2000 . The Procuraduria's campaign on forced sterilisation provides one example where the fallout was politically costly for Fujimori. Introduced by Fujimori in September I995, sterilisation campaigns, or 'Voluntary Anti-contraceptive Surgery' (AQV), were aggressively implemented by Health Ministry personnel from spring 1996 onwards. Furthermore, this was conducted with considerable international support and funding, the project briefly becoming the largest recipient of USAID family planning funds in the Western Hemisphere. $^{76}$

Rumours of abuses began to circulate among NGOs and the church, and with claims arriving at the Defensoría, Villanueva announced an official investigation on 27 December I997. The ombudsman's report, published exactly one month later, documented in detail nine cases of sterilisation that contravened the victims' human rights and official government guidelines. ${ }^{77}$ The exposure and subsequent public and international censure led to a dramatic reduction in AQV procedures, falling from $\mathrm{I} 20,086$ in 1997 to 27,996 in 1998 , and constituted a serious embarrassment for Fujmori. ${ }^{78}$

\section{The Military Justice System}

The Defensoría was also not averse to strongly criticizing the military. The arbitrary arrest of General Robles in November 1996 was publicly criticised

${ }^{74}$ Santistevan, 22 February 2006. $\quad{ }^{75}$ Youngers, 'Promoting Human Rights', p. 74.

${ }^{76}$ Hearing of the US Congressional Committee on International Relations, 25 February 1998.

77 Defensoría del Pueblo, Informe sobre la aplicación de la anticoncepción quirúrgica voluntaria I (Lima I998).

${ }^{78}$ Figures from Ministry of Health. Cited in Defensoría del Pueblo, La aplicación de la anticoncepción quirúrgica y los derechos reproductivos III. Informe Defensorial no. 69. (Lima 2002), p. 136. 
as illegal by the Defensoría, prompting a sharp rebuke from the supreme military council. ${ }^{\mathbf{7 9}}$

In January I997, the Defensoría established a Special Commission to analyse military justice and the military justice code, presided over by the Defensor in Constitutional Affairs, Samuel Abad. This elicited an immediate and abrasive response from the military establishment. ${ }^{80}$ The military justice code was not reformed until after the transition from the Fujimori regime, but related issues such as the 'faceless judges,' in any case due to be abolished in October I 997, were fertile ground for action by the institution. ${ }^{81}$

\section{Playing to its Strengths}

In Latin America generally, the ombudsman model has commonly been assigned an accountability mandate in the broadest sense, working in concert with other accountability agencies and engaging in the non-judicial defence and promotion of human rights. In Peru, the Defensoría applied itself to emulating the political function that such offices have assumed throughout Latin America, namely, making politically potent links between different human rights issues that officials often prefer to approach separately. ${ }^{82}$ This was assisted by the procedural flexibility of the ombudsman. Building on O'Donnell's definition of appointed institutions, the ability of the institution to access different modes of resolution - including proactive and reactive engagement, non-confrontation where possible, and the use of formal and informal channels of resolution - proved to be valuable assets.

\section{Setting the agenda}

The agenda of any ombudsman is largely informed by the political context in which they operate, along with the need to define institutional and

79 Ungar, Elusive Reform, p. 39. On 26 November 1996 General Robles, a retired Major General of the Peruvian army, was forcibly arrested on charges of 'insulting the Armed Forces and general mendacity.' This followed his accusation that senior military officers had been involved in a recent attempt to bomb a TV station in Puno. Robles was already a marked man, having publicly revealed in 1993 that Peru's National Intelligence Service (SIN) had set up a 'death squad', the notorious Colina Group. His arrest was widely condemned within and outside Peru and he was granted amnesty in early December.

80 In 'Bronca de Fueros', La República, i6 February I 997.

81 'Defensor del Pueblo, Jorge Santistevan, Plantea: Deben Desaparecer "Jueces Sin Rostro", La República, 26 January 1997. Under emergency terrorist laws adopted by the Fujimori government in 1992 many individuals were subjected to arbitrary detention and military trial with few legal guarantees. The 'faceless judges' refers to the practice of trying the accused before a panel of judges with their faces concealed by balaclavas, ostensibly to protect their identity. Due to lapse at the end of I997, under strong domestic and international pressure the Fujimori regime relented and did not extend this power.

${ }^{82}$ Ungar, Elusive Reform, p. 37. 
operational parameters vis-à-vis other accountability actors and their respective arenas of action. The operational environment faced by the Defensoria in 1996, combined with its breadth of jurisdiction, gave the institution the ability to improvise and adapt to changing circumstances. This ensured that whilst priority was given to a civil and political agenda, attention was also paid to the two other areas of its mandate laid out in Article I62: state administration and public services.

The Defensoría outlined its priorities in its first annual report presented to congress. These placed, in order of importance, the right to life, the right to liberty, women's rights, those affected by the legacy of conflict, native communities, constitutional matters and finally vulnerable groups such as the young, disabled and aged, as areas of institutional concern. ${ }^{83}$ The internal structures of the Defensoría were also an important indicator of how the agenda was defined, with special offices and programmes created in the area of women's rights, constitutional affairs, indigenous people, prison reform and public services. The absence of specialised offices to deal with certain issues, such as corruption and racism, may indicate areas where the institution was less willing or able to enter.

In the political and civil realm, until 1998 the Defensoría steered clear of entering the legal controversy surrounding elections, leaving this instead to a disparate group of lawyers and opposition figures. Selecting issues on the periphery of the political drama being played out in the courts and on the floor of congress served two key purposes. Firstly, it signalled the institution relevance of the Defensoría for ordinary Peruvians, highlighting the historical absence of such a connection between state and society. Secondly, it contributed to the institution's image of political neutrality within the Peruvian political and institutional apparatus, so bolstering its authority within the state.

\section{Activating the mandate}

During the Fujimori era, human rights and a diverse set of political and civil violations formed a significant part of the Defensoría's total caseload and, as Table 2 shows, such issues continued to be important following the transition, constituting 32.5 per cent of total cases in 200I-2002. The most common violations were to do with disappearances, judicial malpractice, police misconduct and prison conditions. However, throughout the period analysed here, it is striking to note that a consistent 50 per cent or more of all cases concerned state maladministration, especially in the areas of pensions, wages and social benefits. Finally, complaints targeting public services were 
Table 2. Total cases received by area $1999-2002^{1}$

\begin{abstract}
Cases received by area
Political and civil rights

State Administration

Public Services

Others $^{2}$

Electoral supervision

Total
\end{abstract}

$\begin{array}{rr}\text { I } 999 & 2000 \\ \text { I I ,622 } & \text { I } 4,448 \\ 21,880 & 26,855 \\ 3,73 \text { I } & 2,993 \\ \text { I, I66 } & \text { I,798 } \\ 709 & 467 \\ 39,108 & 46,561\end{array}$

2002

2 I, I 58

26,733

4,339

I 2,860

I, 556

65,090

Source: Annual Reports accessed at: www.ombudsman.gob.pe

${ }^{1}$ Comparative data from 1996 to 1998 is unavailable at this time due to variations in methodology.

2 'Others' includes cases on women's rights, prisons, police supervision, and native communities.

considerable, averaging io per cent of the total and focusing on tariffs, quality of service and access.

In reality, of the thousands of cases received each year, only very limited use was made of those mechanisms that could be deemed ex ante accountability mechanisms, such as legislative initiatives. ${ }^{84}$ While recognising the potential for the ombudsman to exploit its proactive faculties, the reactive element of the Defensoría's mandate must be considered fundamental. In the prevailing political context, this function assumed an added significance. The Defensoría, in effect, became the only reliable complaint-handling mechanism within the state apparatus.

\section{Avoiding political conflict}

The Defensoría presented itself as a neutral arbiter capable of resolving social conflict. It quickly achieved recognition for its work with vulnerable groups in Peruvian society, contributing to its social base of legitimacy. Furthermore, the Defensoría's skill in negotiating outside strictly legal parameters contributed to its reputation as an effective political operator and also distinguished it from the confrontational approach adopted by much of the fragmented but vocal opposition. As Javier Ciurlizza observed:

In the case of the Constitutional Tribunal it was a foregone conclusion. The Constitutional Tribunal was not going to negotiate with the government to arrive at a solution. The Defensoría could and did negotiate with the government, with Fujimori, and with Montesinos. ${ }^{85}$

${ }^{84}$ Some 33 legislative initiatives were submitted to Congress from 1996-2000; Annual Reports submitted to Congress 1996-200 I, accessed at: www.ombudsman.gob.pe.

85 Author's interview with Director of the Catholic University Human Rights Department Javier Ciurlizza, 24 August 2005. Mediation generally occurred through government ministries, although Santistevan did hold a number of meetings with Vladimir Montesinos to discuss the details of the Ad-Hoc Commission. 
The reticence of the institution to strike a more forthright tone with the Fujimori administration did not go unnoted and it was not immune from criticism. However, many within and outside the institution recognised that direct confrontation with the regime would pose a threat to the very existence of the Defensoría. ${ }^{86}$ It also appears likely that the protection afforded by its allies before 2000 would not have been sufficient to ward off a concerted congressional attack.

Arguably, international attention, though supportive of the Defensoria, was not willing or able to guarantee its security until the year 2000 approached and agendas shifted. Given the fragmentation of the opposition, the Defensoría could not rely on sufficient social mobilisation in the event that the regime decided to dismantle the institution, or, as was the more likely outcome, render it impotent through other means. Furthermore, rivalries were present within the opposition and many politicians may have been wary of allowing Santistevan to become their cause célèbre. ${ }^{87}$

\section{Formal and informal mechanisms to resolution}

Given the collapse of horizontal controls, the capacity of the ombudsman model to seek resolution through mediation and persuasion rather than through institutional or legal procedures proved to be an asset. Public pronouncements and special reports were the tools most commonly used by the Defensoría to maintain a presence in the public domain and exert some compelling influence on state authorities. These special reports - some 79 of which were issued between 1996 and $200 \mathrm{I}$ - were targeted toward strategic campaigns and issues and were accompanied by media attention and the collaboration of international agencies in their production. ${ }^{88}$

Despite the overall political context, the Defensoría did achieve a reasonable degree of compliance, with 52 per cent of total recommendations issued over the period under examination attended to by recipient state institutions. ${ }^{89}$ This was largely attributed not only to the sound basis of the Defensoría's recommendations and public standing of the institution, but also to the ability of the institution to enter into informal processes of solution-oriented negotiation with offending institutions rather than subject them to public exposure. This method of resolution was most common in matters of an administrative nature. In the areas of human rights violations

${ }^{86}$ Ciurlizza, 24 August 2005.

87 See Catherine Conaghan, Fujimori's Peru: Deception in the Public Sphere (Pittsburgh 2005), p. 135 .

88 Issues included forced sterilization (AQV), arbitrary police detention, faulty electrical installations, pollution and others. Available at www.ombudsman.gob.pe.

89 Annual Reports submitted to Congress 1996-2001. Data for 1998-1999 is not available. 
or alleged corrupt practices the authorities were predictably less open to dialogue. ${ }^{\mathbf{9 0}}$

Finally, it should be recognised that sometimes resolution was not possible. Powerful veto players such as the executive, congress and the military could present insurmountable obstacles. The military's recourse to arbitrary power placed certain issues, such as the location of politically sensitive detainees or unjust decisions laid down by military justice, out of bounds. ${ }^{91}$ The same can be said of the allegations of corruption surrounding Montesinos and the SIN.

A further complication in addressing state maladministration, particularly pertinent to the issue of pensions, was financial in nature. According to one official at the Defensoría, while in the majority of cases, over 80 per cent were resolved in line with the Defensoria's recommendations, that figure dropped to less than io per cent when the cases had an economic component. $^{92}$

\section{Public legitimacy}

The image of the Defensoría as a democratic institution pitched against an increasingly authoritarian executive most clearly resonated among the political community of Lima. In a poll conducted in Metropolitan Lima in August 2000, the Defensoría was recognised as the institution/actor contributing most to strengthening democracy (32\%), followed by youth and student groups (2 I \%) and the media (I I \%). ${ }^{93}$ Graph 3 illustrates the popularity of the Defensor del Pueblo from August I 996 to September 2000. As can be observed, the approval rating was around 50 per cent for much of this period, rising to a high of 64 per cent in 2000.

Graph 4 indicates a progressive increase in the institution's caseload, with a total of 16,478 cases in 1997 rising sharply to 34,7 I 5 in 1998 , and continuing to climb throughout the decade reaching 59,867 in 2001. In part, this reflects supply and demand dynamics; increasing the supply of institutional channels inevitably encourages demand. In a country such as Peru, where the state had traditionally neglected the institutional sphere of representative democracy, an institution such as the Defensoría enjoyed added novelty value. ${ }^{\mathbf{9 4}}$

The intention behind the creation of the Defensoria may have been to offer a therapeutic rather than heuristic device. This could have been its fate,

\footnotetext{
90 Alza, 6 July 2005. 91 Abad, 6 July 2005.

92 Dante Mendoza (Deputy Defensor for State Administration) in interview with Fredrik Uggla, November 29, 200I. Quoted in Uggla, 'The Ombudsman', p. 438.

93 'Organizaciones que cumplen un papel importante en el fortalecimiento de la democracia'. Survey conducted by DATUM Internacional, August 2000.

94 Rubio, 7 September 2005.
} 


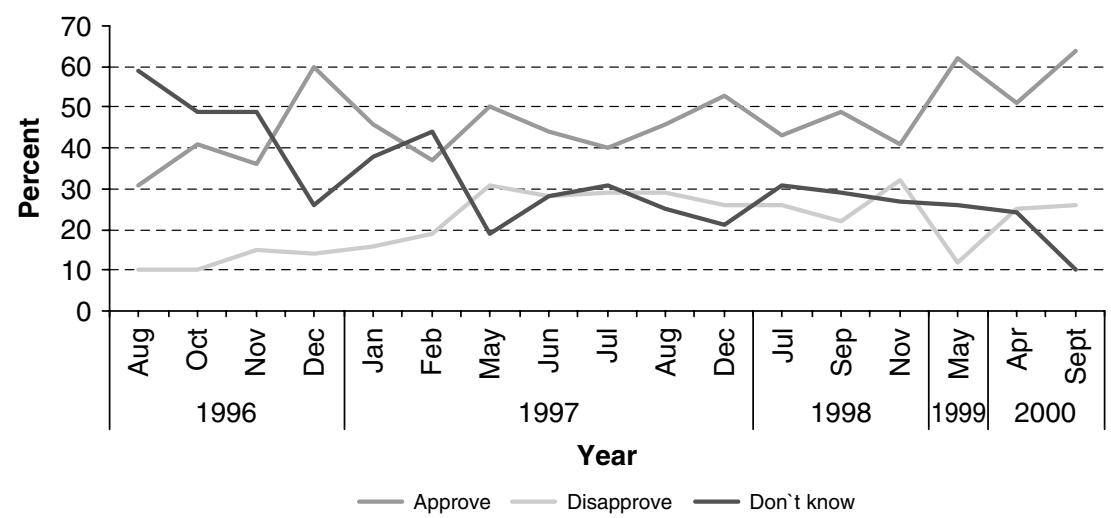

Graph 3. Popularity of the Defensor del Pueblo 1996-2000. Source: Datum International, opinion surveys conducted in Lima 1996-2000.

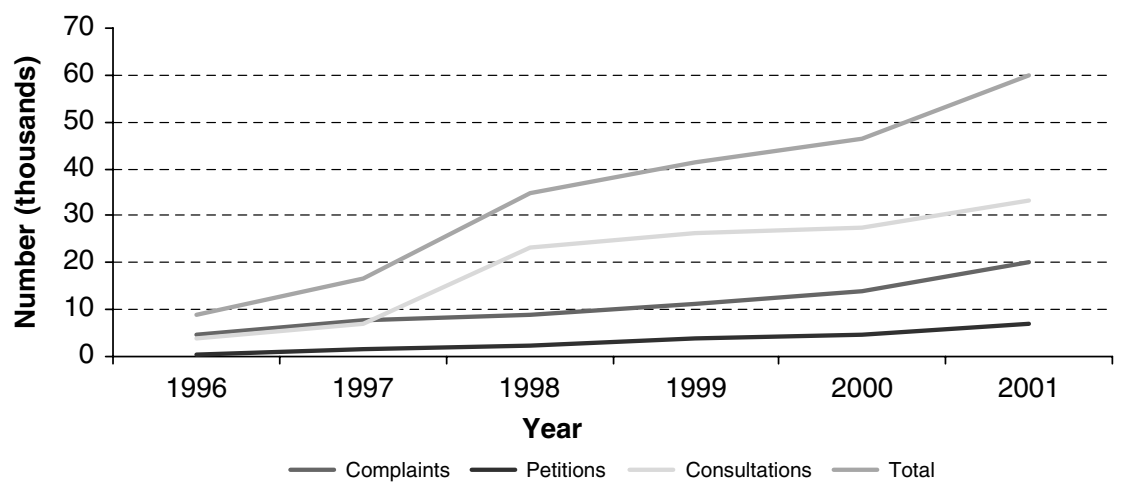

Graph 4. Total Cases Received during 1996-200I. Source: Annual Reports submitted to Congress 1996-200I.

but with the collaboration of the media, the institution was able to present an image not only of efficiency, but also efficacy. Articles such as that published in El Comercio on I I June 1999 with the title 'Defensoría del Pueblo Resolves $7 \mathrm{I}$ per cent of Complaints During 1998-1999' were not uncommon. ${ }^{95}$ However, the Defensoría also received more general criticism in, or through, the press from both the pro and anti-government camps, government and civil society representatives charging the ombudsman with either abusive, or conversely insufficient, use of its powers. ${ }^{96}$

95 "Defensoría del Pueblo Resolvio 7I Por Ciento de las Quejas y Denuncias Durante Periodo i 998-i999." El Comercio, i I June i 999.

96 See Caretas, no. I623, I 5 June 2000, p. 32 ; Ideele, No. I 27, Apr-May 2000, p. I 3. 


\section{The 2000 Elections and the Fall of Fujimori}

The events of 2000 provided a showcase for the Defensoría's strengths and limitations as an accountability agent, particularly with respect to its interaction with state agencies, social and external actors across different arenas of accountability during the elections.

\section{Defining an electoral mandate}

Internationally, ombudsmen are rarely appointed to oversee elections. The vote is one of the most controlled and protected rights in a democracy and is not necessarily natural territory for the ombudsman. As previously noted, the Defensoría developed a low-key but significant presence in the political domain without incurring high political costs. Yet despite this evident caution, indications of the Defensoría's future role were apparent early on. Asked in I 998 about the political controversy surrounding the dismantling of the Constitutional Tribunal, Santistevan commented:

Does what has occurred have a re-election motive? I do not know, although many have raised this suspicion. In any case, if the population does not agree with this, their most persuasive power lies through the ballot box. ${ }^{97}$

Although the institution did not establish a methodology for electoral intervention before 1998, Santistevan was clearly focused more on the process than on the politics of presidential re-election. The broad mandate contained in Article 162 allowed for the proactive expansion of the institution's jurisdiction into this arena, deriving its authority from Article $3 \mathrm{I}$ of the Constitution, which provided the legal guarantee of participation.

In 1998 the Defensoría would begin to develop an electoral role. To this end, it played a limited supervisory role in the municipal elections of I 998 , primarily in those areas subject to state of emergency provisions. ${ }^{98}$ The Defensoría produced a number of reports on the barriers to voting confronted by the populations of these areas and others focused on vulnerable groups, such as native communities and the disabled. Furthermore, the institution worked closely with domestic accountability agencies such as Transparencia. ${ }^{99}$ On the basis of this experience, the Defensoría expanded its operations considerably in the municipal elections of July 1999, ${ }^{100}$ and, with

97 La Fortaleza del Defensor, in QUEHACER, DESCO i i 2 (March-April i 998), pp. 4-1 3.

${ }_{98}$ In the 1998 municipal elections the Defensoría fielded 25 people to supervise in the cities of Huamanga, Huancavelica, Huancayo and Andahuaylas.

99 The Defensoría, with evidence provided by Transparencia, successfully petitioned the JNE to annul the 1998 municipal election in Vinchos, Ayacucho due to voting irregularities.

100 roo people were fielded by the Defensoría in the departments of Ayacucho, Apurimac, Huancavelica, Huanaco, Junin y Pasco. 
the support of diverse political parties and media outlets, published its programme of supervision for the forthcoming 2000 elections in late December. ${ }^{101}$

\section{Activation and retaliation}

The careful manner in which the Defensoría negotiated entry into election supervision signalled the delicate game the institution was playing. Not only vulnerable to politically-motivated attack in the short term, over the longer term Santistevan had no guarantee that Fujimori would not still be in office after April. ${ }^{102}$ As such, the official document that emerged in December looked to diminish political conflict, highlighting the inter-institutional agreement signed with the National Office of Electoral Procedures (ONPE). ${ }^{103}$

The Defensoría staked its claim to a supervisory role 'to ensure the neutrality of the state' during the elections, distinct from the observer status held by domestic and international civil society, or the oversight role undertaken by the National Elections Board (JNE) ${ }^{104}$ This new addition to the oversight framework met with resistance. In early 2000, the JNE issued a controversial communiqué asserting that only the JNE had 'supervisory' powers in the election and that any usurpation of its powers would be met by legal action. ${ }^{105}$

Such hostile action by regime clients against the Defensoría often backfired, eliciting strong criticism from international observers such as the head of the OAS mission, former Guatemalan vice-president Eduardo Stein, the Carter Center and ambassadors, and inadvertently encouraging public sympathy for the embattled institution. ${ }^{106}$ Santistevan proceeded to announce that the Defensoría would field a team of 1,316 people on election day and would provide 'supervisory' functions at 36 per cent of all the country's mesas (polling stations). ${ }^{\mathbf{1 0 7}}$

\section{The signature scandal}

On 29 February 2000, El Comercio broke news of the first serious allegation of electoral fraud, directly implicating personnel of the ONPE. The timing was critical, coinciding with the arrival of the OAS Electoral Mission (MOE).

\footnotetext{
101 Resolucion Defensorial, no. 63-99/DP, published 23 December I999.

102 Author's interview with APRODEH advisor, Wilfredo Ardito, I6 July 2005.

103 Abad, I4 July 2005.

104 Defensoría del Pueblo, Elecciones 2000: Informe de supervisión de la Defensoría del Pueblo (Lima 2000), pp. 37-8.

105 Gestión, 7 March 2000.

107 El Comercio, 26 March 2000.
} 
Previously the OAS had kept a low profile in its monitoring role. This time, led by Eduardo Stein, they and other international observers such as the Carter Center adopted a more robust position on the elections, proving unwilling to play only 'mute witness to the process'. 108

At the centre of this controversy was witness testimony to an alleged 'signature factory' that was provided to the Carter Center-NDI mission and the Defensoría. Santistevan subsequently turned over the videotape testimony to the JNE and called for an investigation. ${ }^{109}$ Possibly reflecting an increase in confidence within the institution as a result of the international presence, Santistevan, alongside opposition figures and the media, kept up pressure on the issue through legal petition. ${ }^{\mathbf{1 1 0}}$

Given the flagrant use of illegal devices by congress to undercut any checks and balances on the regime, the Defensoria's intervention in the electoral process was met by fierce political opposition. Characteristic of the regime, the offensive against the Defensoría consisted of a dual strategy: a legal questioning of the institution's mandate by the JNE and congress, and a smear campaign against Santistevan in the tabloid press. ${ }^{111}$ Accused of leaking the story to the press and acting illegally by presenting the information to the JNE instead of the Ministerio Público, Santistevan became the focus of a proposed congressional investigation for misconduct. ${ }^{112}$ This threat was 'postponed', following the intervention of external actors, including the US and UK ambassadors, in support of the Defensoría. ${ }^{113}$

\section{April and the second round}

Alongside others in civil society and the media, the Defensoría began to document and report on the electoral process. The report published following the first round documented a range of unfair practices and concluded that the electoral process was 'defective'.114 This judgement was echoed more forcefully by many in civil society and abroad. ${ }^{\mathbf{1 1 5}}$

Concerted political pressure resulted in the ONPE (and therefore the government) reluctantly conceding a second round by the slimmest of

108 Eduardo Stein in repost to the ONPE chief's suggestion that observers be barred from making declarations before the elections. El Comercio, 29 March 2000.

109 El Comercio, 5 March 2000.

110 When a special prosecutor was appointed to bury the issue, Santistevan requested that the ONPE and JNE be given access to the petitions seized to conduct a parallel investigation. Expreso, io March 2000.

111 Santistevan was included in the telaraña roja reports, where he was cast as dedicated to toppling the government through false propaganda.

112 La República, 6 March 2000. ${ }_{113}$ Gestión, 8 March 2000; El Comercio, 8 March 2000.

114 Defensoría del Pueblo, Elecciones 2000, p. 104.

115 See Carter Center-NDI, Peru Elections 2000: Final Report (Atlanta 2000). 
margins. ${ }^{116}$ For the regime, the strategy now turned to bulldozing through a second round victory as quickly as possible. The opposition identified the ONPE as the regime's weak spot, especially regarding the computation of the vote. ${ }^{117}$

The second round was set for 28 May, providing little time for scrutiny of the process. In order to assuage the concerns of Stein and the MOE, José Portillo, the boss of ONPE, agreed to set up a 'working group' including the Defensoría, which was charged with evaluating the institution's computer systems. Despite strong protest from the OAS and other accountability agencies, including the Defensoría, the government refused to postpone the second round. Santistevan subsequently announced that the Defensoria would be withdrawing from all election day observation activities. Debate within the Peruvian press (not aligned with the regime), such as the magazines Caretas, Que Hacer and Ideele, while generally supportive of the role of the Defensoría, voiced frustration at the institution's lack of powers reflecting an almost total breakdown of political accountability at a systemic level. ${ }^{118}$

\section{The downfall of Fujimori}

Ambiguity persisted following the election victory of Fujimori. Even Stein, with no hard evidence at his disposal, was reluctant to apply the word 'fraud' in his report to the Permanent Council of the OAS on 3I May 2000. Domestically, the opposition regrouped for what Alejando Toledo, their de facto leader, dubbed 'the third round'; an effort to force change through social mobilisation. Although the Defensoría did not call explicitly for new elections, the institution gave moral weight to the opposition. The blue jackets of the Defensoría became a familiar sight at public demonstrations, including during the dramatic Marcha de los Cuatro Suyos held on 28 July. ${ }^{119}$

The Defensoría and Santistevan had built a considerable profile as a lone legitimate democratic state entity. In international circles, the institution was considered a serious operator. When an OAS high-level mission arrived in late June to promote a reform agenda, the Defensoría became a key partner in promoting a Mesa de Diálogo between the government, opposition parties and members of civil society. Through such exposure, Santistevan become a

116 The final vote tally gave Fujimori $49.84 \%$ to Toledo's $40.39 \%$. Victory in the first round requires $50 \%$ plus one.

117 Defensoría del Pueblo, Elecciones 2000, p. 100.

118 See 'Control de daños o daños sin control', Ideele, no. I 28, June 2000.

119 The Marcha de los Cuatro Suyos was organised by Toledo in protest at Fujimori's reelection. Los Cuatro Suyos refers to the four corners of the Incan kingdom. Incan imagery would subsequently become a common feature of Toledo's presidential campaign. 
prominent public figure, especially in Lima. ${ }^{\mathbf{1 2 0}}$ Following its non-confrontational protocol, the Defensoría did not exploit this political capital to confront the government. However, commentators in the press repeatedly suggested that Santistevan would be a suitable candidate to head a provisional government. ${ }^{121}$

It is uncertain whether Fujimori could have served out a full term. In any case, this decision was largely taken out of his hands. On I 4 September 2000, the discovery of the 'Vladi-videos' was announced live on Canal N, showing Fujimori's 'intelligence advisor,' Montesinos, bribing a prominent congressman. ${ }^{122}$ This media-exposed bombshell set in motion the breakdown of the regime. With his denial of knowledge of the corruption scandal sounding increasingly hollow, Fujimori finally chose to flee the country in November 2000.

\section{Conclusion}

The Peruvian Defensoría constitutes a rare, possibly unique example of a horizontal accountability mechanism created and successfully activated within an increasingly authoritarian context. ${ }^{\mathbf{1 2 3}}$ However, it is also important to reflect on the limitations of the Defensoria, or those of any one institution, in being able to effect systematic change.

In evaluating the performance of the institution, this article has raised a number of questions; above all, how the institution achieved a position of strength sufficient not only to survive the adverse political context, but also to make an important contribution toward encouraging the democratic political transformation of November 2000. It has been argued that the answer lies within three principle domains: (I) the robustness of the institution's foundations; (2) the capacity of the first appointee and personnel, and; (3) the ability of the institution to build alliances able to enhance accountability.

With regard to institutional design, the broad mandate contained in Article I62 was crucial for introducing a dynamic of strategic control for the ombudsman, as was apparent in the case of electoral supervision. Institutional underpinning also extended to financial resources, with the Defensoría

120 One poll in November 2000 placed Santistevan fifth most popular potential presidential candidate nationwide, though far behind Toledo. Datum International, poll conducted 4-7 November 2000.

121 See Ideele, no. I 32, April-May 2000, p. 5-18, Caretas, no. I623, p. 3 I.

122 The so-called 'Vladi-videos' showed Montesinos bribing everyone from media executives and congressman to election officials.

123 Other non-democratic states with ombudsmen include Kazakhstan, Kyrgyzstan and Uzbekistan in Eurasia; Pakistan in Asia; Rwanda, Sudan, Tunisia and Zimbabwe in Africa. No reliable data exists to evaluate the effectiveness of these institutions. 
appearing not to have been subject to political interference in budget allocation. This stability was reinforced by a constant flow of funds from international sources.

The personal qualities displayed by the first appointee can be considered a determining factor in the success or failure of an ombudsman. Although criticised in some quarters for his personal protagonism, ${ }^{124}$ Santistevan was a highly effective orator and political operator. His political ambitions may provide one explanation for the notable persistence and growing assertiveness of the Defensoría over time. This article has also pointed to a common deficit in the literature by highlighting the role of senior personnel who individually set area agendas, develop internal capacity and cultivate allies.

The ability of an institution to outlive its initial founder is the litmus test of institutionalisation. It is certainly likely that the decision by Santistevan to enter the presidential race in 2000 contributed to the political isolation of his successor and introduced a de-stabilising political dynamic. Internal anxiety now surrounds upcoming appointment proceedings and relations between the institution and congress after 2000 have veered from the combative to the indifferent. That said, while Santistevan's political ambitions quickly faltered, public approval for the Defensoría remained resilient. ${ }^{125}$ Popular support appears to have been shored up by the development of a strong local level presence under the leadership of Walter Albán (200 I-2005). Reflecting the perceived failure of the re-instated institutions to fulfil their democratic obligations to the polity, the novelty value of the Defensoría endured beyond the Fujimori era. ${ }^{126}$

In discussing the institution's oversight agenda, the classical dual mandate of enhancing judicial control over the public bureaucracy and parliamentary scrutiny over the executive requires consideration. Fujimori, while possibly wishing for the former, also gained the latter. Mindful of the potential repercussions of holding the executive to account, the Defensoría was extremely tactical in its modus operandi. This raises the question of whether all three explanatory factors, and their component parts, have an equal or distinct bearing on institutional performance. Without attempting to resolve this issue here, it seems apparent that the ability of senior personnel to accurately gauge the political temperature during the Fujimori years was central to maintaining the Defensoría's independence. The flexibility of the institution in formal and operational terms, demonstrated by the application

124 Ciurlizza, 24 August 2005.

$12546.4 \%$ public approval ratings in poll conducted by Universidad de Lima on $2-3$ December 2006.

126 Only $40 \%$ of Peruvians polled in the 2005 Latinobarómetro agreed that democracy is preferable to any other kind of government. 
of a results-oriented methodology, may have been more decisive in terms of institutional impact.

This leads on to the third factor under consideration, the ability of the ombudsman to build alliances which can enhance accountability. The institution's activities and actions within this rubric were varied and complex. While affirming the general utility of accountability theory as a framework with which to assess the function of the ombudsman, analysis of the Peruvian experience also suggests the need for further refinement of the theory and its sub-types.

As stated in the introduction, the question of horizontal accountability, initially developed as a tool to analyse weak or low-quality democracies, may have a wider applicability to a range of hybrid regimes. The existence of the Defensoría was an indication of the semi-authoritarian nature of the Fujimori regime. Caught between the competing desires to control and maintain a veneer of democratic normalcy, Fujimori allowed a diminished, albeit not insignificant, form of horizontal accountability to exist. The persistence of the Defensoría suggests not so much its capacity to defend or strengthen democracy, as its ability to remain independent as the surrounding political context degenerated.

It is also suggested here that definitions of horizontal and social accountability and their conceptual sub-types - both arenas of interaction and resources brought to bear by different actors - require further refinement. Notwithstanding important common characteristics, there is sufficient evidence to suggest that the Peruvian ombudsman was - and remains - a special case among horizontal accountability institutions. This has implications for the more general theoretical framework on accountability. For instance, O'Donnell's narrow definition of horizontal accountability, which focuses exclusively on control and punishment of unlawful actions or omission by agents or agencies of the state, is, arguably, insufficient to account fully for the horizontal political controls and political sanctions employed by the ombudsman. Similarly, the institution's mandate to supervise public administration and assume the role of mediator suggests a political control function that lies beyond purely legal parameters.

At the level of appointed institutions, the ombudsman displays a number of distinct characteristics with significant consequences in terms of its accountability function. Features shared by few other horizontal accountability institutions include a broad and unrestrictive rights mandate, the direct interaction and reactive duty to the citizen, and a mandate to generate public information on rights and legality for public dissemination. The distinctive position of this institution amongst horizontal control agencies is also reflected in the interaction of the Defensoria with social actors outside the state, including the press. Ideally, such interaction is mutually reinforcing, 


\section{Thomas Pegram}

bringing an array of strategies and types of accountability to bear on a given issue. It is suggested here that the ombudsman's role in providing access to marginalised and excluded groups and facilitating processes of judicial and legislative recourse may be of particular significance when assessing its role within the overall framework of social accountability.

At its most fundamental level, the Defensoría provides an example of a successful institutional creation in a country where democratic institutions have been tough to establish and even more difficult to sustain. The extent to which the experience of the Defensoría can be instructive for other processes of institution-building in Peru or elsewhere may be debatable, but such considerations should not obscure the early achievements of this institution. 